\author{
Marcin Brycz \\ University of Gdańsk \\ e-mail: marcin.brycz@ug.edu.pl \\ ORCID:0000-0002-9017-8915

\section{Teresa Kamińska} \\ University of Gdańsk \\ e-mail: teresa.kaminska@ug.edu.pl \\ ORCID: 0000-0002-0434-2871
}

\title{
PENSION FUNDS AND FDI. IS THERE A LINK?
}

\section{FUNDUSZE EMERYTALNE A BEZPOŚREDNIE INWESTYCJE ZAGRANICZNE. CZY ISTNIEJE ZWIĄZEK MIĘDZY NIMI?}

DOI: $10.15611 / \mathrm{pn} .2019 .9 .02$

JEL Classification: H55, F21

Summary: The significant factors determining Foreign Direct Investments are trade openness, economic growth and the institutional profile of the country. Among the latter determinants, pension system privatization attracts foreign investors, as it gives them a signal that the country's macroeconomic stability is going to improve. FDI are beneficial for economic development, especially for economies in transition. The question arises whether the degree of pension system privatization attracts FDI to developed economies. To answer this, Dunning's Investment Development Path was applied for 44 countries over the period 2006-2016 from the OECD database. The first step consisted of clustering data to obtain the IDP stage for each country in a given year. The second step was a panel estimate. The outcome indicates that when a country is in a lower IDP stage (up to 2), the size of the private pension funds positively affects FDI inflow. When the country reaches the higher stage, private pension funds' size does not seem to affect the FDI inflow.

Keywords: pension funds, FDI, Investment Development Path, panel data.

Streszczenie: W literaturze ekonomicznej uznaje się, że otwartość gospodarki, wzrost gospodarczy oraz czynniki instutucjonalne przyciagają Bezpośrednie Inwestycje Zagraniczne (BIZ). Prywatyzacja systemu emerytalnego może przyczynić się do przyciagnięcia BIZ, ponieważ kraj, gdzie ona ma miejsce, spostrzegany jest jako prowadzący odpowiedzialną politykę makroekonomiczną. Wiele badań dotyczących powyższego zagadnienia odnosi się do krajów rozwijających się, jednak czy zależność ta będzie istotna także dla krajów rozwiniętych? Aby udzielić odpowiedzi na powyższe pytanie badawcze zastosowano teorię ścieżki rozwoju inwestycji dla danych z 44 krajów w latach 2006-2016 dostępnych w bazie 
OECD. W pierwszym kroku ustalono etap na ścieżce rozwoju inwestycji dla każdego kraju w każdym roku na podstawie technik aglomeracji. W drugim etapie zastosowano regresje panelową. Z przeprowadzonych badań wynika, że prywatne fundusze emerytalne przyciagają BIZ do krajów na niskim poziomie ścieżki, natomiast wśród krajów, które znajdują się na wysokim poziomie ścieżki, nie zaobserwowano wpływu wielkości prywatyzacji emerytur na BIZ.

Słowa kluczowe: fundusze emerytalne, BIZ, ścieżka rozwoju inwestycji, dane panelowe.

\section{Introduction}

Pension funds are playing a greater and greater role in the economy, as society is getting older. Before excess transfers occur, pension funds usually constitute in which large amount of assets are hold. Many countries have decided to privatize pension funds. This in turn leads to flooding the equity and bond markets with saved cash. Such a case can be beneficial to the financial markets as volatility is decreased (Thomas, Spataro, and Mathew, 2014). Foreign direct investment is among many macroeconomic phenomena affected by private pension funds. The link between FDI and private pension funds goes through better macroeconomic, financial and fiscal conditions of the country that implemented pension funds' privatization. This in turn attracts investors to locate their capital and increase FDI inflow.

Most research concerns development or transition cases, as FDI inflow is relatively high and pension reform newly introduced. The link between private pension funds and FDI inflow is not well described in the literature regarding developed countries.

In 1981 Augusto Pinochet introduced a strong neoliberal agenda in Chile. The state-run pay-as-you-go system was reformed to be replaced by managed private pension funds. In the following decade Chile experienced massive FDI inflow (Del Sol and Kogan, 2007). Since Chile's success, dozens of countries have introduced a similar institutional solution to the pension solvency problem - mainly in other Latin countries and Eastern Europe. Reece and Sam (2012) conducted panel data, fixed effect model research on the link between pension funds' privatization and FDI inflow in the developing countries of Eastern Europe, Latin America and East Asia. The research indicated the strong positive influence on capital inflow. Their methodology was to add a variable representing pension funds' privatization to well-known FDI determinants and check whether is it significant.

There are many channels by which private pension funds can impact FDI. Private pension funds seem to better a country's fiscal and macroeconomic condition in the long run (Kay, 2000; Reece and Sam, 2012), but on the other hand the privatization process leads to higher public deficit and debt in the initial stage. As rating agencies generally do not pay attention to the implicit pension debt, decreasing pension debt and increasing public one can lower the country's rating (Cuevas, Gonzalez, López- 
-Marmolejo, and Lombardo, 2008). One should heed the sample selection in analyzing private pension fund impact on the economy. Altiparmakov and Nedeljković (2018) evaluated the link between pension funds' privatization and economic growth in Latin America and Eastern Europe. They found limited evidence of positive growth in Latin America and lack of evidence in Eastern Europe. The reason for such a relation is financing privatization reform from the sovereign debt. The extensive literature on Dunning's (1981) Investment Development Path combines a country's development and foreign direct investment. In light of this theory one can group countries by their maturity based on FDI and GDP. Using the IDP approach gives the possibility to group countries by their development stage and check whether private pension funds also attract FDI to developed countries.

The aim of the study is to assess whether private pension funds attract FDI on different development stages. The authors put forward the hypothesis that private pension funds attract FDI at lower development stages described by IDP. Such a suggestion comes from the literature review, as investors perceive a country with private pensions as safer and expect it to develop faster.

In order to test the hypothesis, panel data estimation was applied with fixed effects. In the model, popular FDI inflow determinants are added to the variable reflecting pension funds' privatization. An estimation is performed for five subsamples - countries belonging to the investment development path stage.

\section{Investment Development Path}

The concept of the IDP was developed by J.H. Dunning as an extension and transformation of the eclectic paradigm, known in literature as Ownership (specific advantages of ownership), and Location (specific advantages of internalisation (OLI)) (Dunning, 1981, pp. 30-64); without knowing that it is difficult - according to its creator - to describe the mechanism of the internationalization of a country from stage to stage. Both concepts were revised at least ten times from the original OLI presentation in $1975,{ }^{1}$ therefore their reminder will be based on Dunning's initial and recent publications on these issues. The idea of the investment development path is based on distinguishing the stages of the country's development depending on their propensities to engage directly in foreign investment (Figure 1). This in turn can be explained by the use of an earlier eclectic theory which suggests that (Dunning, 1980, pp. 30-64):

- the nature and size of enterprises' activities abroad depend on the resources they have or can benefit from access to it, e.g. technology, know-how, human capital, telecommunications infrastructure, resources or other forms that generate assets that competitors neither possess nor have access to on such favourable terms (specific property advantages);

\footnotetext{
${ }_{1}^{1}$ The original version was presented by J.H. Dunning and P. Buckley during the conference at the Academy of International Business in Manchester (Dunning, 2001, p. 188).
} 
- assuming that an enterprise has certain property advantages necessary to engage in foreign direct investment, it must consider their suitability only for themselves or sell the right to use them to entities abroad (specific advantages of internalisation);

- there must be natural factors or assets created in the host country that increase the attractiveness of FDI, to combine them with their advantages or add new value to them, rather than to produce in the home country (specific location advantages).

Dunning - in numerous publications - states that the properties and significance of these advantages are not a constant characteristic of the country (enterprises), but change over time, which means that a specific configuration of OLI variables attracts various forms of FDI with various types of activities (the search for new market, natural resources, strategic assets, and efficiency) that are not mutually exclusive (Dunning, 2001, pp. 177-178). However, in a given period, the more national enterprises have specific property advantages in relation to enterprises in other countries, the stronger the incentives to internalize, and the more it is in their interest to exploit the advantages belonging to foreign companies, the greater the likelihood that both corporations and countries will engage in international operations (production). Similarly, he explained the theory in dynamic terms; changes in the country's position regarding the outflow and inflow of investments can be explained by changes in the ownership advantage and the advantages of internalization of enterprises in a given country in relation to enterprises in other countries or, respectively, changes in the location of specific assets (equipment) in relation to other countries (Dunning, 1981, p. 31). At present - thanks to the common knowledge of Dunning's theory among economists - it seems that the interrelationship between the three variables OLI and their mutual interpenetration seem obvious, and that with the passage of time, the separate identity of the variables becomes more and more difficult to justify. Finally, the successful coordination of the advantages of ownership of domestic and foreign enterprises with their own advantages of location, as well as the way each advantage influences and is influenced by the allocation of resources, determines the level that the economy is able to maintain or increase the ability to create well-being in time (Dunning, 2001, pp. 178-179).

The concept of the construction of the investment development path (Figure 1) shows the relationship between the investment position of the country and the level of economic development in relation to other countries. The phase of economic advancement is determined by the gross national product per capita (empirical studies described in the literature on the subject include gross domestic product); this measure was adopted as an indicator of absolute and comparative competitive advantages (Dunning and Narula, 1993, p. 5). As a synthetic measure of the investment position of the country, the difference between the cumulative value of the export and import of investments (cumulative investment resource) is usually treated, namely: 


$$
N O I=E I V_{n}-I I V_{n},
$$

where: NOI (net outward investment) - cumulative net investment value $n ; E I V_{n}$ (export investment value) - cumulative value of export of investment from country $n, I I V_{n}$ (import investment value) - cumulated value of investment imports to country $n$.

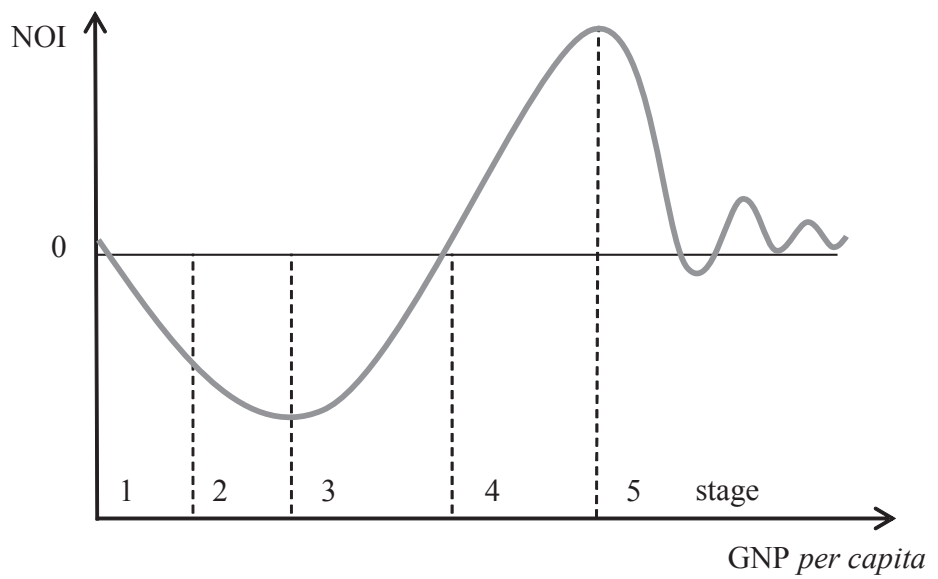

Fig. 1. Idea diagram of Investment Development Path

Source: (Dunning and Narula, 1993, p. 79; Narula, 1994, p. 78).

The investment development path therefore explains the internationalization of enterprises at macroeconomic level by means of a cumulative pool of foreign direct investment, and NOI determines the position of the country at a given time and evolves with the increase in GDP per capita. According to the IDP model, national economies go through five stages of the relationship between the GNP per capita income and the position on this path (NOIP) (Dunning and Lundan, 2008, pp. 330-337):

1) pre-industrial stage, advantages derive only from natural assets, very low GNP per capita income and lack of sufficient enterprises for foreign allocation, advantage of ownership and location of the country (undeveloped infrastructure and uneducated labour resources), internationalization process based on state-regulated foreign trade, possible attractiveness of the economy for FDI is the natural resources of the host country;

2) growing income and growing domestic market, as well as improving infrastructure, increasing the attractiveness of the country as a place of FDI investment (import of labour-intensive goods is replaced by production on the spot), but still - despite a pro-development economic policy - the ownership advantage of domestic enterprises is insufficient to equalize the inflow of foreign streams (export of investments at an insignificant level); 
3) the developing country is approaching economic maturity, and the level of income and the structure of the economy are beginning to resemble the attributes of developed countries; the FDI inflow rate slows down due to the deterioration of traditional advantages, and at the same time the investment flow abroad accelerates, the country's technological capabilities change as well as the demand for higher quality goods, whose production is launched in domestic enterprises, gradually displacing foreign production; the competitiveness of domestic enterprises increases as they start to use their ownership advantage and the nature of the location advantage changes, e.g. the incentive of low-cost work is replaced by the increase in innovation and the level of education;

4) the competitiveness of enterprises increases thanks to the emergence of ownership advantage and location resulting from neo-technological distinguishing factors, which leads to the equalization of the inflow and outflow FDI streams and changes in the geographic structure towards cooperation of countries at the same stage and more and more cooperative connections between and within entities associated with the joint ownership of shares; domestic enterprises begin to benefit from internalization and compete effectively with foreign ones also on a global scale;

5) this stage was introduced only in 1996; the level of economic advancement of the economy is close to stage 4; the current trends have stabilized, i.e. the level of inflow and outflow of FDI between countries with a high level of economic development, which show the greatest tendency to allocate resources (the value of net investment exports fluctuates around zero), the hierarchical production of substitute goods dominates, the role of the state as a regulator of economic activity disappears, or at least strongly decreases, considering the importance of international corporations.

Taking into account the challenges facing the global economy in the 21 st century, and above all the energy problems, climate change and conservation of the natural environment for future generations, it may be necessary to identify a sixth stage. FDI, as a carrier of technological progress, can definitely improve the parameters of the greenhouse effect, especially with the active participation of international corporations, even in the context of corporate social responsibility. In that context IDP could be an inspiration to investigate modern forms of international cooperation in the service sector. That is why it is worth examining likely correlation between FDI flows and pension funds' performance in order to pursue higher returns.

A practical application of the Investment Development Path is categorizing countries by its stage. From the econometric point of view, clustering can be helpful. Yasar, Acikalin, and Gezer (2015) used Hierarchical Agglomerative Clustering to determine five IDP stages by 59 variables reflecting economic development. Boudier-Bensebaa (2008) used Ward's linkage clustering by net outward investment and GDP per capita, Dunning's (1981) original equation was also estimated. 


\section{Data and estimation}

The dataset comes from the OECD database and consists of forty four countries over the period 2006-2016 (409 observations, the panel is unbalanced as some data were not available). Below there are the following variables (Table 1), chosen from the literature review. The variables are determinants of FDI inflow plus a share of private pension assets in GDP. According to the hypothesis on the link between pensions' privatization and FDI inflow, privpGDP should be significant and explain some variance of FDI.

Table 1. Name of variables used in the study

\begin{tabular}{|c|l|l|}
\hline No & Abbreviation & \multicolumn{1}{c|}{ Description } \\
\hline 1 & GDPpc & Gross Domestic Product at current PPP per capita \\
\hline 2 & NOIpc & $\begin{array}{l}\text { Net Outward Investment per capita at current dollar. Calculated as the } \\
\text { difference between outward and inward stock }\end{array}$ \\
\hline 3 & Trade_op & Trade openness, sum of exports and import as a share of GDP \\
\hline 4 & GDPgr & GDP growth per capita \\
\hline 5 & res & Foreign Direct Investment restrictions all-industry index \\
\hline 6 & privpGDP & Share of private pension assets in GDP \\
\hline 7 & fdiinf & Foreign Direct Investment inward flow as \% of GDP \\
\hline 8 & ds & Dunning's IDP stage, based on Ward's linkage clustering \\
\hline
\end{tabular}

Source: own elaboration.

The first part of the research is to identify the country's IDP stage in each year. The first step, therefore, is to estimate IDP to indicate whether such a relation in the whole sample exists. There are various methods to do this (Fonseca, Mendonca, and Passos, 2016). The authors used Dunning's (1981) original equation:

$$
N O I p c=\alpha+\beta G D P p c_{t}+\gamma G D P p c_{t}^{2}+\mu_{t} .
$$

Table 2. Panel Estimation of Equation 2

\begin{tabular}{|l|c|c|c|c|}
\hline \multicolumn{1}{|c|}{ Variable } & Coef. Std. & Err & $t$ & $P$ \\
\hline GDPpc & 1.126561 & .2360183 & 4.77 & 0.000 \\
\hline GDPpc $^{2}$ & -.0000134 & $2.52 \mathrm{e}-06$ & -5.32 & 0.000 \\
\hline constant & -18883.22 & 4936.099 & -3.83 & 0.000 \\
\hline
\end{tabular}

Dependent: NOIpc, panel estimation. $F(2,41)=14.41$, between $R^{2}=0.41$

Source: own elaboration. 
The estimation results of equation (2) (Table 2) indicate the significance of the Investment Development Path in the dataset. Gross Domestic Product per capita has a positive sign. The low level of GDPpc leads to a negative investment position (NOIpc). A rise in GDPpc will better the investment position and eventually lower it as the GDPpc square weigh more.

Heaving proved IDP over the whole sample, one proceeds to identify the country's IDP stage. This is possible by clustering countries in five groups in each year by their investment position and GDPpc. In this method it is assumed that there are countries in each IDP stage.

In the scatter diagram (Figure 2) there is fitted Investment Development Path. On the lower-left side one can find South Africa and Brazil, which have low GDP and a near balanced investment position. Moving from left to right in the scatter diagram, a higher GDP and better investment position are observed (at first negative then positive), finally the fitted curve goes downward as the theory suggests.

At the end of the first step of the research, Ward's linkage clustering is applied in order to put the countries in the appropriate group - the IDP stage. For each year the countries were put into five clusters. Another issue arises when the same country is

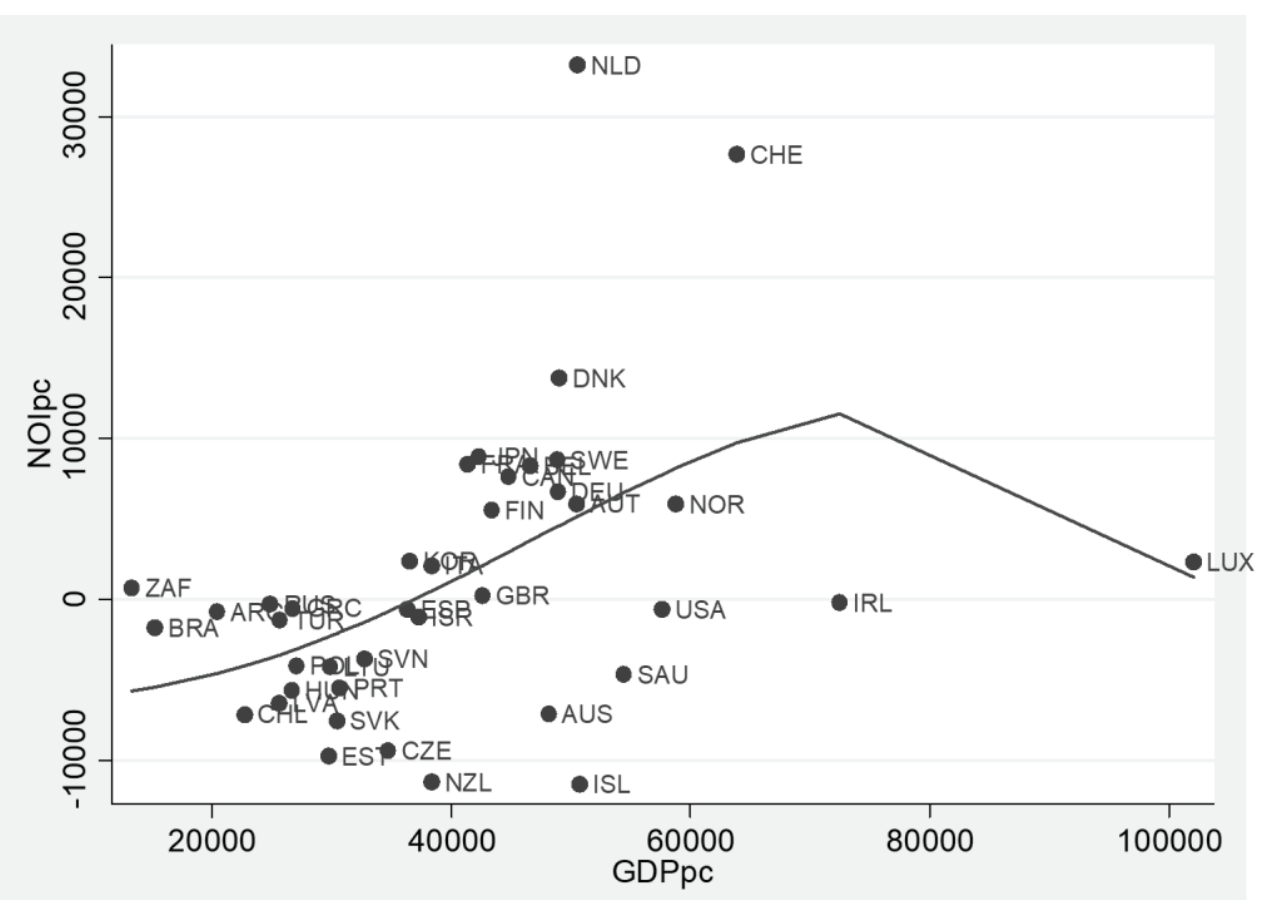

Fig. 2. Scatter diagram of GDPpc and net outward investment in 2016 with fitted curve Source: own elaboration. 
assigned to two or more stages. This can be due to the economy's development or change in other countries' group position. Nevertheless this problem can be overcome by splitting two or more IDP stages into one group.

In Figure 3 countries are shown which were attached to both groups. There are twelve such cases out of forty four in the database. Highly developed countries were in group which consisted of the IDP stage: first, second and third (ds. $<4)$ only in one year out of eleven.

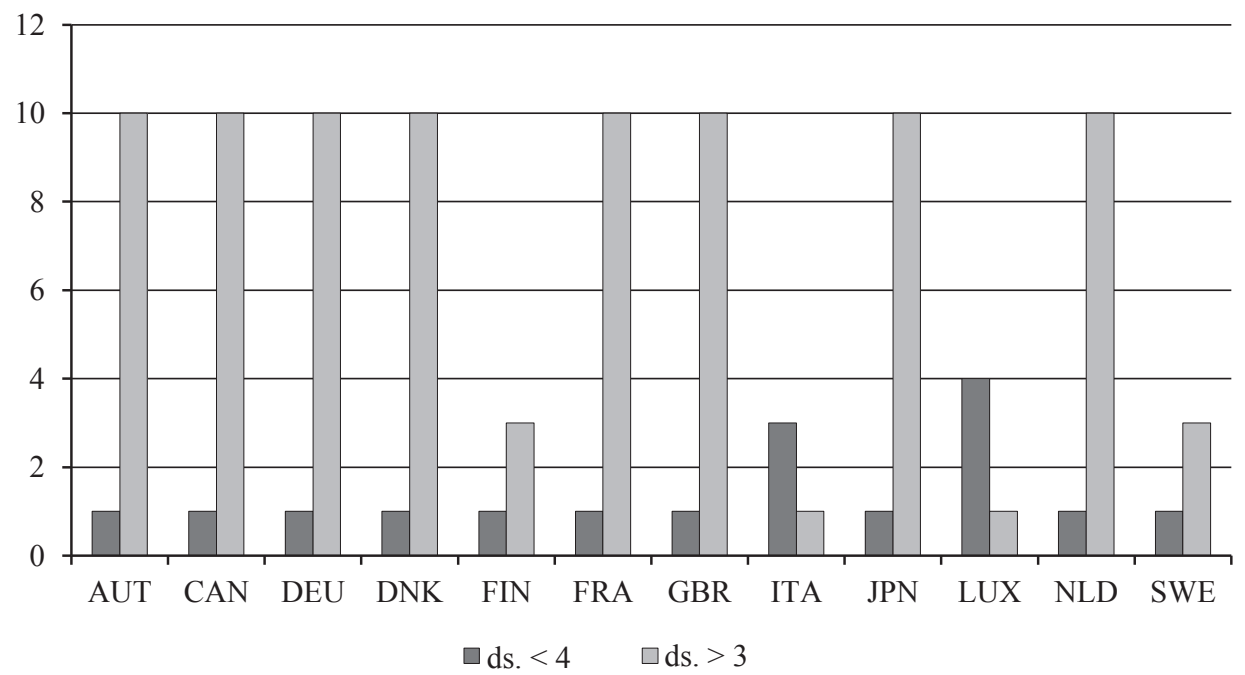

Fig. 3. Countries accounted to both aggregated stages ( $3^{\text {th }}$ and lower and $4^{\text {th }}$ and higher)

ds. $<4$ - IDP stage 1,2,3; ds. $>3$ - IDP stage: 4 and 5. In the graph are shown countries that were assigned to both groups, although in different years.

Source: the authors' calculation.

The second part of the research is to estimate the panel in which the FDI inflow is the dependent variable with the following popular FDI determinants: GDP growth, GDP per capita, capital restrictions, trade openness and private pension assets as a share of GDP. The last variable is needed to check whether private pensions attract FDI inflow. The estimation is performed in two groups of countries - less developed in terms of investment development path (stages 1 to 3 ) and developed (stages 4 to 5).

The number of observations differs across variables as a result of missing data. Variable res - capital restriction FDI ranges between near 0 and .5. This indicator ranges between 0 and 1, which implies low FDI restriction among the sample.

As data are organized in a panel, the problem of choosing the effects arises. On the one hand the inferencing particular group e.g. EU or OECD countries, heuristic suggests use of the Fixed Effect Estimator as the authors assume each 
Table 3. Descriptive statistic

\begin{tabular}{|l|l|l|l|l|l|}
\hline \multicolumn{1}{|c|}{ Variable } & Obs & \multicolumn{1}{c|}{ Mean } & Std. Dev. & \multicolumn{1}{c|}{ Min } & Max \\
\hline Fdiinf & 387 & 3.569681 & 6.178001 & .0279137 & 74.26585 \\
\hline ds. & 408 & 2.921569 & 1.46498 & 1 & 5 \\
\hline GDPpc & 399 & 32249.97 & 14935.48 & 3351.378 & 102553.9 \\
\hline Tradeop & 377 & 88.64585 & 54.38332 & 22.10598 & 410.1716 \\
\hline GDPgr & 400 & 2.329437 & 3.748103 & -14.81416 & 25.55729 \\
\hline Res & 312 & .0993333 & .1013629 & .004 & .449 \\
\hline privpGDP & 342 & 45.0283 & 62.24351 & .0111928 & 253.9517 \\
\hline
\end{tabular}

Source: the authors' calculations.

subject has time-invariant characteristic ( $u_{i}$ is fixed in equation $\left.3 \mathrm{~b}\right)$. The Random Effects Estimator is rather used when data are drawn from the population (Baltagi, 2005).

$$
\begin{gathered}
y_{i t}=\alpha_{i}+\beta^{\prime} x_{i t}+u_{i t}, \\
u_{i t}=u_{i}+v_{i t},
\end{gathered}
$$

where: $y_{i t}$ - dependent variable, $x_{i t}$ - vector of independent variables; $i$ - country, $t$ - time (year), $u_{i t}$ - error term that consists of $u_{i}$-individual-specific effect and $v_{i t}$ reminder disturbance.

The estimation of equation (3) is applied to a sub-sample of developing countries (IDP-stage 3 and lower, ds $<4$ ) and to developed countries - IDP stages 4 and 5 (ds. > 3). Finally the estimation in countries of each stage is performed to investigate robustness.

Before estimation, a battery of tests were applied. At first pooled data (dependent fdiif, independents: GDPpc, GDPgr, tradeop, res) were estimated, followed by tests:

1. The LM test using auxiliary regression for adding $\mathrm{GDPpc}^{2}$, when the test rejects the null hypothesis that the added variable equals 0 , indicates nonlinear dependence. ${ }^{2}$

2. Panel diagnostics: joint significance of differing group means, the Breusch-Pagan test, and the Hausman test.

In the first group $(d s<4)$ nonlinear relation is observed $\left(x^{2}(1)=42.1, p<0.001\right)$, group means differ significantly as $\mathbf{F}(34,133)=3.03, p<0.001$; the Breusch-Pagan tests indicate models with random effects $x^{2}(1)>27.3, p<0.001$, and the Hausman test $x^{2}(5)>10, p=0.07$ confirms that random effects are consistent. Therefore the Random Effects Estimator is used.

${ }^{2}$ Investment Development Path is nonlinear, although in a particular subsample i.e. stage 3 relation can be linear. 
In the second group $(d s>3)$, nonlinear relation is confirmed $\left(x^{2}(1)=22.9\right.$, $p<0.001)$, group means do not differ significantly $F(18,69)=1.49, p=0.12$; the Breusch-Pagan test indicates pooled models either $x^{2}(1)>0.56, p=0.45$.

In the next step, panel data models for countries on IDP stage 3 and lower was built. The first model consists of only gross domestic product $p c$, its square and private pension variable, than the rest of the FDI determinants are added.

Table 4. Estimation of FDI determinants for countries in stage 3 and lower

\begin{tabular}{|l|c|c|c|c|}
\hline \multicolumn{1}{|c|}{ Variable } & Model 1 & Model 2 & Model 3 & Model 4 \\
\hline GDPpc & $-0.0004^{* * *}$ & $-0.0003^{* * *}$ & $-0.0003^{* * *}$ & $-0.0003 * * *$ \\
\hline GDPpc $^{\mathrm{a}}$ & $5.32 \mathrm{e}-09^{* * *}$ & $4.63 \mathrm{e}-09^{* * *}$ & $4.66 \mathrm{e}-09^{* * *}$ & $4.57 \mathrm{e}-09 * * *$ \\
\hline privpGDP & 0.0163 & $0.0229^{*}$ & $0.0215^{*}$ & $0.0227^{* *}$ \\
\hline Tradeop & & $0.0156^{* * *}$ & $0.0132^{* *}$ & 0.0090 \\
\hline GDPgr & & & 0.1210 & $0.2456^{* * *}$ \\
\hline Res & & & & $-9.3217^{*}$ \\
\hline constant & $8.1058^{* * *}$ & $6.5204^{* * *}$ & $6.3295^{* * *}$ & $6.7002^{* * *}$ \\
\hline Obs. & 208 & 206 & 206 & \\
\hline
\end{tabular}

${ }^{a}$ Investment Development Path is nonlinear, although in a particular subsample i.e. stage 3 relation can be linear.

Standard errors in parenthesis. ${ }^{* * *}-p<.001 ; * * p<.05 ; * p<.1$.

Source: the authors' calculations.

The estimation results indicate the significance of private pension funds as the FDI determinant, when the country is in stages 1 to 3 . An increase in private pension assets leads to an increase in foreign direct investment, although not in all specifications the private pension assets variable was significant at 0.05 level.

Table 5. Estimation of FDI determinants for countries in stages 4 and 5

\begin{tabular}{|l|c|c|c|c|}
\hline \multicolumn{1}{|c|}{ Variable } & Model 1 & Model 2 & Model 3 & Model 4 \\
\hline GDPpc & $-0.0015^{* *}$ & $-0.0011^{*}$ & $-0.0016^{* * *}$ & $-0.0014^{* * *}$ \\
\hline GDPpc2 & $1.78 \mathrm{e}-08^{* * *}$ & $1.28 \mathrm{e}-08^{* *}$ & $1.54 \mathrm{e}-08^{* * *}$ & $1.38 \mathrm{e}-08^{* * *}$ \\
\hline privpGDP & 0.0128 & 0.0126 & 0.0126 & 0.0054 \\
\hline Tradeop & & $0.0710^{* *}$ & $0.0590^{* * *}$ & $0.0647 * * *$ \\
\hline GDPgr & & & $1.5005^{* * *}$ & $1.8511^{* * *}$ \\
\hline Res & & & & 5.8747 \\
\hline Constant & 32.6233 & 21.5106 & $33.3152^{* * *}$ & $26.3939 * * *$ \\
\hline Obs. & 118 & 118 & 118 & 89 \\
\hline
\end{tabular}

Standard errors in parenthesis. ${ }^{* * *}-p<.001 ;{ }^{* *} p<.05 ;{ }^{*} p<.1$.

Source: the authors' calculations. 
In the subsample of countries in stages 4 and 5 investment development path only GDP growth and trade openness are the significant determinant of FDI inflow. Pension funds' assets as a share of GDP does not seem to influence foreign direct investment.

In the final step of verifying the hypothesis on private pension funds' link with FDI inflow there is the estimation model for countries with all five IDP stages separately. As the theory suggests, each stage is linear, therefore only strong FDI determinants are included in each regression (GDPgr, trade openness, FDI restriction).

Table 6. Estimation of FDI determinants in different development stage

\begin{tabular}{|c|c|c|c|c|c|}
\hline Variable & IDP 1 & IDP 2 & IDP 3 & IDP 4 & IDP 5 \\
\hline privpGDP & 0.0523 & $0.0566^{* * *}$ & $0.0209 * * *$ & -0.0192 & -0.0077 \\
\hline Tradeop & $0.1601 * * *$ & -0.0007 & $0.0572 * * *$ & $0.1487 * * *$ & $0.0411^{*}$ \\
\hline GDPgr & 0.0751 & $0.2191 * * *$ & 0.0475 & $4.24628 *$ & $2.0291 * * *$ \\
\hline Res & 21.8690 & $-10.6392 * * *$ & $9.4586^{*}$ & 21.9991 & -6.6584 \\
\hline constant & $-11.9748^{* *}$ & $2.2842 * * *$ & $-3.5231 * * *$ & $-15.2811 * * *$ & -3.1143 \\
\hline Model & FE & WLS & WLS & BETWEEN & BETWEEN \\
\hline $\begin{array}{l}\text { Obs/cross- } \\
\text { sections }\end{array}$ & $32 / 10$ & $93 / 22$ & $37 / 20$ & 13 & 17 \\
\hline Tests & $\begin{array}{l}\text { Within } \mathrm{R}^{2}=0.45 \\
\mathrm{~F}(13,18)= \\
6.76^{* * *} \\
\mathrm{DW}=1.72\end{array}$ & $\begin{array}{l}\mathrm{R}^{2}=0.54 \\
\mathrm{~F}(4,88)=28 * * *\end{array}$ & $\begin{array}{l}\mathrm{R}^{2}=0.71 \\
\mathrm{~F}(4,32)=23 * * *\end{array}$ & $\begin{array}{l}\mathrm{R}^{2}=0.90 \\
\mathrm{~F}(4,8)=30^{* * *} \\
\text { normality of resi- } \\
\text { dual } \chi^{2}(2)=3.29\end{array}$ & $\begin{array}{l}\mathrm{R} 2=0.90 \\
\mathrm{~F}(4,8)=30^{* * *} \\
\text { normality } \\
\text { of residual } \\
\chi^{2}(2)=1.42\end{array}$ \\
\hline
\end{tabular}

Standard errors in parenthesis. ${ }^{* * *}-p<.001 ;{ }^{* *} p<.05 ; *^{*} p<.1$.

Source: the authors' calculations.

In the first development stage, trade openness seems to be the only FDI determinant $(p<0.001)$, in the second one economic growth, FDI restriction and private pension funds' assets are influencing FDI. In the third one pension funds attract FDI strongly together with trade openness and restriction on investment from abroad weigh less than in the previous stage, in the fourth and fifth trade openness and economic growth respectively affect FDI inflows. The above findings confirm that private pension funds attract FDI, but in the stage of rapid economic growth the second and third on the investment development path.

\section{Conclusion}

The aim of this study was to evaluate the link between the size of private pension funds' assets (indicated by the ratio to GDP) and FDI inflow in a particular development stage. As the literature review suggests that privatization and private 
pension funds attract foreign direct investment through the macroeconomic condition of the country in the long run, therefore improving investors' expectations for the future of the state, this phenomenon happens mostly in the less developed countries.

Testing the procedure of the above hypothesis consisted of several stages. At the beginning, Dunning's theory on development stages was tested on our dataset by regressing net outward investment per capita by gross domestic product per capita and it's square. Having confirmed that the chosen data set reflects stages on IDP, the dataset was clustered to assign a country in each year to a particular IDP stage. Next the link between the size of private pension funds' assets and FDI inflows was enacted. The whole sample was divided into two groups (developing and developed countries) and finally in each IDP stage the link was tested.

The estimation results indicate that private pension funds' assets significantly attract foreign direct investment to countries at the lower stage of development - in the subset of developing countries (stages 1 to 3 ). In the second group (stages 4 to 5) there is no significant impact of the size of pension funds' assets on the FDI inflows.

The conclusion from the estimation of each of the IDP stages provides a picture of FDI attractors. In stages 2 and 3, private pension funds' assets brings FDI. In the remining stages other determinants play a role - in each stage a different one.

Some limitations of the study come from choosing the panel estimation. The nature of the data - the assignment of countries to different stages in different years can create a disturbance between and within the effects. For instance, in one group there can be strong between effects, while in another within effects.

\section{Bibliography}

Altiparmakov, N., and Nedeljković, M. (2018). Does pension privatization increase economic growth? Evidence from Latin America and Eastern Europe. Journal of Pension Economics \& Finance, 17(1), 46-84.

Boudier-Bensebaa, F. (2008). FDI-assisted Development in light of the investment development path paradigm: Evidence from Central and Eastern European countries. Transnational Corporations, 17(1).

Baltagi, B. H. (2005), Econometric analysis of panel data, John Wiley \& Sons, Ltd.

Cuevas, A., Gonzalez, M., López-Marmolejo, A., and Lombardo, D. (2008). Pension privatization and country risk (IMF Working Paper No. 08/195).

Del Sol, P., and Kogan, J. (2007). Regional Competitive Advantage Based on Pioneering Economic Reforms: The Case of Chilean FDI. Journal of International Business Studies, 38(6), 901-927.

Dunning, J. H. (1980). Towards an eclectic theory of international production. Journal of International Business Studies, (11), 30-64.

Dunning, J. H. (1981). Explaining the International Direct Investment Position of Countries. Towards a Dynamic or Developmental Approach, Weltwirschaftliches Archiv, 119, 30-64.

Dunning, J. H. (2001). The eclectic (OLI) paradigm of international production: past, present and future. International Journal of the Economics and Business, 8(2), 177-188.

Dunning, J. H., and Lundan, S. M. (2008). Multinational Enterprises and the Global Economy. Cheltenham: Edward Elgar. 
Dunning, J.H., and Narula, R. (1993). Transpacific foreign direct investments and the investment development path: the record assessed. Essays in International Business, (10).

Fonseca, M.R., Mendonca, A., and Passos, J., (2016). The paradigm of the investment development path: does it hold for Portugal? Evidence for the period 1990-2011 (Working Paper CEsA CSG No. 139/2016).

Kay, S. (2000). Recent changes in Latin American welfare states: is there social dumping? Journal of European Social Policy, 10(2), 185-203.

Narula, R. (1994). Transpacific foreign direct investments and the investment development path: the record assessed, South Carolina Essays in International Business, (10).

Reece, Ch., Sam, A.G., (2012), Impact of Pension Privatization on Foreign Direct Investment, World Development, 40(2), 291-302.

Thomas, A., Spataro, L., and Mathew, N. (2014). Pension funds and stock market volatility: An empirical analysis of OECD countries, Journal of Financial Stability, 11(2014), 92-103.

Yasar, E., Ac1kalın, S., and Gezer, A. M., (2015). Testing IDP hypothesis by cluster analysis: Which countries in which stage? Procedia Economics and Finance, (23), 1201-1209. 